\title{
CONTROL SYSTEM FOR TEMPERATURE, HUMIDITY AND TIME PARAMETERS ON ZELIO SMART RELAY-BASED WATERING PROCEDURES
}

\author{
Akbar Sujiwa*, Irfan Arif \\ Department of Electrical Engineering \\ University of PGRI Adi Buana Surabaya \\ *Corresponding email address: akbarsujiwa@unipasby.ac.id
}

\begin{abstract}
Watering plants usually done manually using human power. that has risk negligence and inaccuracy. also, in time and cost is not efficient. Another factor that can affect the quality of crops is a factor of humidity and temperature. For those reason, writers made a tool that can work according to the level of humidity and temperature automatically and continuously. This tool uses Zelio Smart Relay as automatic controller. The $808 \mathrm{H} 5 \mathrm{~V} 5$ humidity sensor and LM35 temperature sensor is used as input. The LM35 temperature sensor detect the ambient temperature, whereas 808H5V5 humidity sensor detect ambient air humidity, and time of watering adapted to the Smart Relay timer. The entire sensor input is programmed using ZELIO SOFT 2. Setting the temperature and humidity when the detected $300 \mathrm{C}$ and $>70 \%$ as well as the time shows at $08.30-09.00$ am and $16.00-16.30$ pm the pump will automatically $O N$.
\end{abstract}

Keywords: Zelio Smart Relay, ZELIO SOFT 2, Humidity Sensor 808H5V5, Temperature sensor LM35

\section{INTRODUCTION}

Plant seeds cannot live and develop well if the water in the soil does not meet the needs. The method of watering the seeds is generally done manually, namely by watering the seeds of plants one by one using human power. Manual work always has aspects of negligence and inaccuracy and is less efficient when viewed in terms of time and cost.

In addition to water that functions as a nutrient for plants, there are several environmental factors that can affect plant quality factors. Some factors include humidity and temperature.
The emergence of increasingly sophisticated automated technology equipment in the world of electronics now supports humans to make technological equipment that is able to work automatically, and of course very useful to facilitate human work.

Watering plants can be done automatically by utilizing these technologies, one of which is to use Smart Relay. Smart Relay is a controlling system that can be programmed to control and regulate the watering process which can be adjusted according to the humidity level and temperature.

Using Zelio Smart Relay as an automatic controller and LM35 temperature sensor to detect room temperature, humidity sensor $808 \mathrm{H} 5 \mathrm{~V} 5$ to detect air humidity and timer on a smart relay to set the watering process time [1].

\section{RESEARCH METHODS}

This study discusses the regulation of humidity and room temperature using the Zelio Smart Relay module, $808 \mathrm{H} 5 \mathrm{~V} 5$ module as a humidity sensor, and the LM35 module as a temperature sensor. In this research, hardware design is carried out in the form of a whole series of sensor modules as input and software design in the form of language programs using the ZELIO SOFT 2 application. In completing this study there are several steps to be carried out as shown in Figure 1.

\section{Zelio Smart Relay}

Smart relay is a device that can be programmed by a particular language commonly used in the automation process. Smart relays are small and relatively light in size. Zelio Logic smart relays are designed for automated systems commonly used in industrial and commercial 


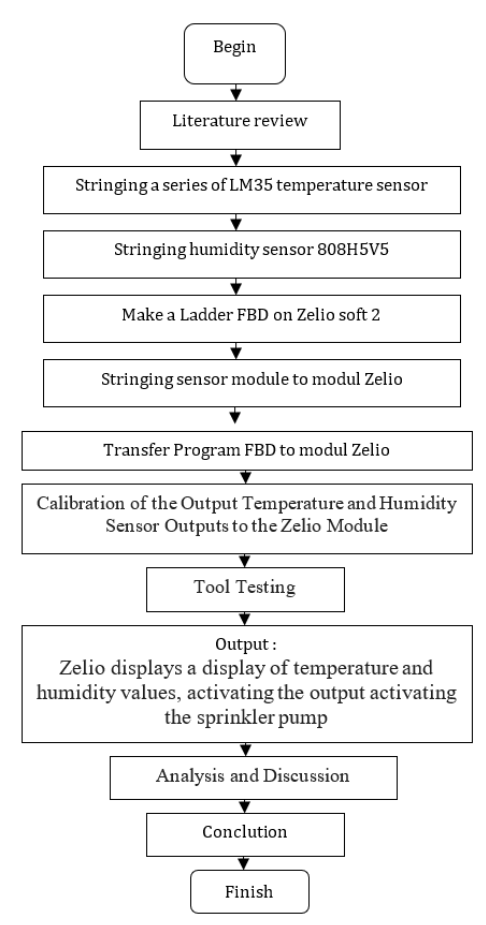

Figure 1. Research Flow Chart

applications [2]. For industrial use, it is usually used for small finishing applications, packaging and production processes. Besides that, it is also used for small scale machines up to large scale ones and sometimes also used for home industries. For the commercial sector or buildings commonly used for rollers, entrances, electrical installations, compressors and others that use automation systems.

The function of smart relay is a special form of microprocessor-based controller that utilizes memory that can be programmed to store instructions with certain rules and can implement special functions such as logic functions, sequencing, timing, counting and arithmetic with the aim of controlling the machines and processes that will be carried out automatically and repeatedly

Smart relay used in this study is a type of Zelio SR2B121BD, has I / 04 pieces of discrete inputs 4 analog inputs and 4 output relays and has a $24 \mathrm{Vdc}$ power supply. Smart relay is a modular Relay that can be expanded. The software used for Smart Relay is Zelio Soft 2.

Which uses ladder diagram language or can also use a function block diagram. Smart relays used can be expanded according to needs. So that input and output can be added to this Smart Relay. Smart relay also has a screen that

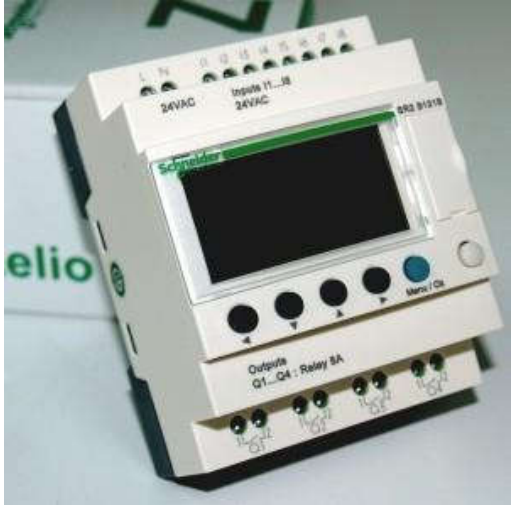

Figure 2. Zelio module

can be used to view or replace programs that have been input into this Smart Relay. On the screen there is also a backlight that is used to illuminate the screen to facilitate reading on the screen. Smart relay also has data backup performed by EEPROM Flash memory. The communication used is the Modbus network [3].

\section{Humidity Sensor $808 H 5 V 5$}

As the input of the humidity sensor used is 808H5V5. This module is designed based on a capacitive humidity sensor. This module is very easy to use as a component and various kinds of moisture measurements and control of a production.

The features contained in the module are cheap, sensor polymer capacitors, the liner output voltage response depends on humidity, high accuracy, can work in a bad environment. The applications of this module are, meteorology instrumentation, Industrial control process, and $\mathrm{RH}$ instrumentation measurement [4].

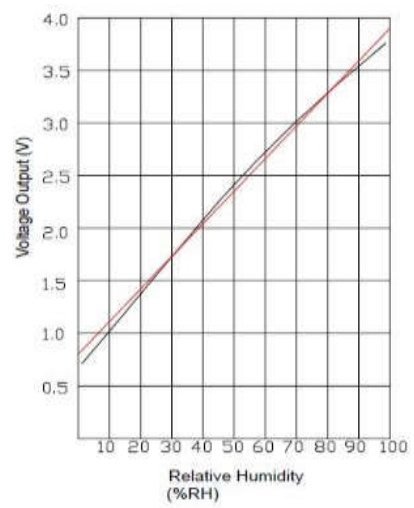

Figure 3. Graph of Voltage and Humidity Correlation 
BEST

Journal of Applied Electrical, Science, \& Technology - University of PGRI Adi Buana Surabaya

p-ISSN 2715-2871

e-ISSN 2714-5247

\section{LM35 Temperature Sensor}

As an input, LM35 temperature sensor is used which is a series of integrated circuit temperature which has a high sensor accuracy, where the output voltage is directly proportional to the temperature (Celsius). This temperature sensor has a low and linear output impedance and can also be used with direct current (DC) and alternating current (AC) sources. LM35 has very low self-heating, which is less than $0.10 \mathrm{C}$, every $60 \mu \mathrm{A}$ from the source [5].

In figure 4. is a temperature sensor circuit with a voltage amplifier. The opamp output voltage can be directly fed to the zelio smart relay module.

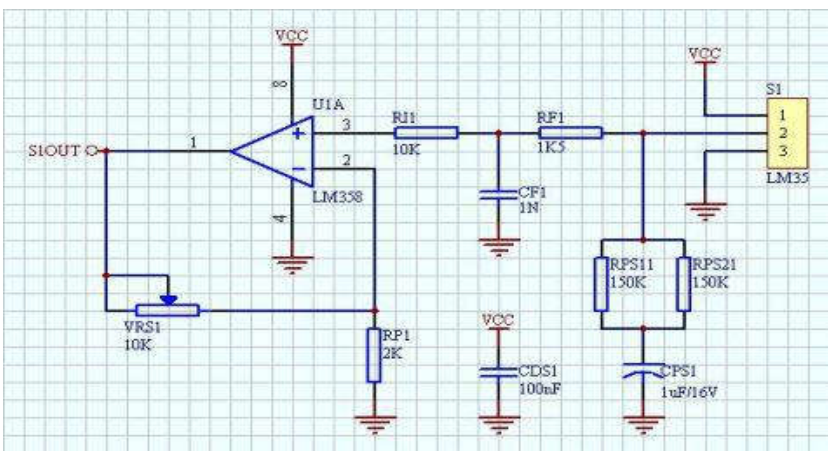

Figure 4. Temperature Sensor circuit

\section{System Design}

The flow chart of the equipment work system can be seen in Figure 5. From the flowchart image above, it starts from pressing the switch on the power supply so that the smart relay is $\mathrm{ON}$ and runs the process to completion.

The first process, the smart relay is ON with $24 \mathrm{Vdc}$ supply voltage and the process starts.

The second process, the Zelio module will read the value of each sensor input. Smart relay input is an 808H5V5 humidity sensor and LM35 temperature sensor has an analog voltage output. If the ambient temperature is around $30 \mathrm{oC}$ or a voltage of $3.00 \mathrm{Vdc}$ and humidity $<70 \%$ or a voltage of around $3.01 \mathrm{Vdc}$ and the flush time is 08:30 - 09:00 and 16:00 - 16:30 the Zelio module will activate the relay to run the pump motor automatically.

The last process, the power supply is turned off, the smart relay will be OFF and the process will be finished.

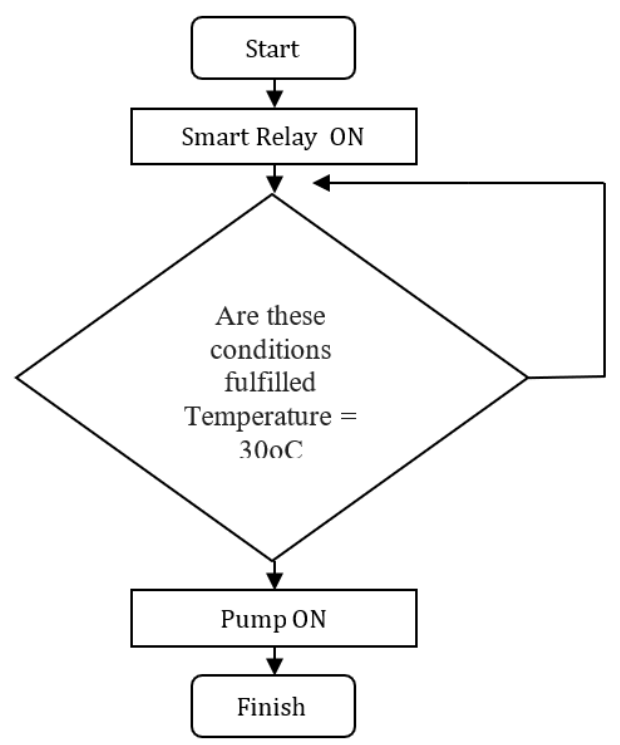

Figure 5. System flow diagram

After the software program in the module has been created next is a whole series of control systems, namely a combination of inputs from each component. Following is the wiring diagram (figure 6.)

Based on Figure 6 it can be seen that the temperature sensor requires a voltage of $12 \mathrm{Vdc}$ while the humidity sensor requires a voltage of 5 $\mathrm{Vdc}$ and Smart relay requires a voltage of 24 Vdc. The voltage output from the 808H5V5 humidity sensor is input to the IB input on the smart relay. The output voltage of the LM35 temperature sensor is input to the IC input. Input $\mathrm{I} 1, \mathrm{I} 2, \mathrm{I} 3, \mathrm{I} 4$ is a discrete input which means having input worth life (1) and dead (0) Input IB, IC, ID, IE in the zelio module is an analog input which means it has input voltage $0 \sim 10$ Vdc, for it is very suitable for use by sensors that have analog outputs such as LM35 and 808H5V5 sensors.

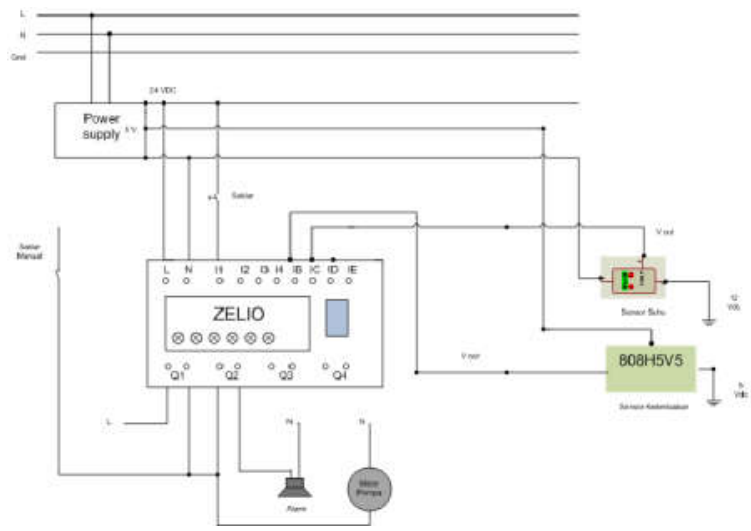

Figure 6. Overall System Wiring Diagram. 


\section{RESULTS AND DISCUSSION}

The results of the steps in making the FBD program on Zelio Soft 2 can be seen in Figure 7.

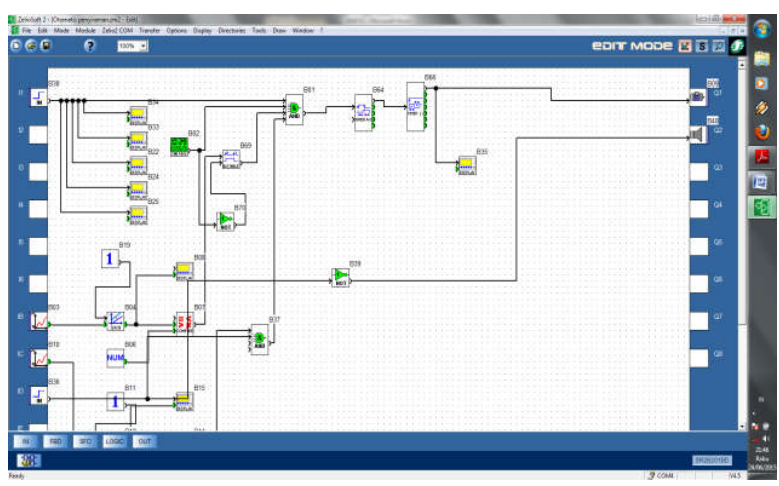

Figure 7. FBD Program on Zelio Soft

It can be seen that input $\mathrm{I} 1$ is a descriptive input, when the switch is pressed then the $\mathrm{ON}$ switch will enter the AND component. Input IB is an analog input from an $808 \mathrm{H} 5 \mathrm{~V} 5$ humidity sensor with an 8-bit ADC that converts the voltage from 0 to $10 \mathrm{~V}$ to digital mapping from $0-255$. The GAIN component in this program functions to convert (mapping) data from 0-255 to $0-100 \%$. And as a comparator uses the COMPARE component with input of a numerical constant of 70 for temperatures $<70 \%$. When the detected humidity is less than $70 \%$, the COMPARE will be active and enter AND. Input IC is input from analog LM35 temperature sensor with 8-bit ADC that converts $0-10 \mathrm{~V}$ voltage into digital mapping $0-255$. The GAIN component in this program functions to convert (mapping) data from $0-255$ to $0-100 \mathrm{oC}$. And as a comparator using the COMPARE component by inputting a $30 \mathrm{oC}$ numeric constant, the COMPARE will be active and enter AND. PROG TIME serves as a timer which is set at 08.30 to 09.00 and 16.00 to 16.30 WIB. Cycling Time functions as a timer for the duration of the pump to work. The display functions to display the reading results on the Zelio Smart Relay screen

From the program the analog voltage of the $808 \mathrm{H} 5 \mathrm{~V} 5$ humidity sensor that ranges from $0 \sim 5 \mathrm{Vdc}$ analog data is then converted to digital data on the FBD program and converts it to a range of $0 \sim 100 \%$ humidity values while the analog voltage at the temperature sensor ranges from $0 \sim 10 \mathrm{Vdc}$ converted to digital data and converted into a range of temperature values $0 \sim$ $100 \mathrm{oC}$. This value of Humidity, temperature and readable timer will vary the work of the sprinkler pump. The analog voltage accuracy of each sensor affects the results of zelio readings that will be displayed on the display. For this reason, the FBD program is calibrated by setting up the GAIN component.

In testing equipment, the tool is placed in an open space. The following are the results of testing of each sensor.

Table 1. Measuring Output Analog LM35

\begin{tabular}{|c|c|c|c|c|}
\hline Date & Time & $\begin{array}{c}\text { Termometer } \\
\left({ }^{\circ} \mathrm{C}\right)\end{array}$ & $\begin{array}{c}\text { Analog } \\
\text { output }\end{array}$ & $\begin{array}{c}\text { Display } \\
\text { Zelio }\left({ }^{\circ} \mathrm{C}\right)\end{array}$ \\
\hline \multirow{2}{*}{$\begin{array}{c}\text { 14-06- } \\
2015\end{array}$} & $\begin{array}{c}08.30- \\
09.00\end{array}$ & 32 & $3,2 \mathrm{Vdc}$ & 31 \\
\cline { 2 - 5 } & $\begin{array}{c}16.00- \\
16.30\end{array}$ & 31 & $3,1 \mathrm{Vdc}$ & 30 \\
\hline \multirow{2}{*}{$\begin{array}{c}15-06- \\
2015\end{array}$} & $\begin{array}{c}08.30- \\
09.00\end{array}$ & 31 & $2,9 \mathrm{Vdc}$ & 30 \\
\cline { 2 - 5 } & $\begin{array}{c}16.00- \\
16.30\end{array}$ & 31 & $2,9 \mathrm{Vdc}$ & 29 \\
\hline \multirow{2}{*}{$\begin{array}{c}16-06- \\
2015\end{array}$} & $\begin{array}{c}08.30- \\
09.00\end{array}$ & 31 & $3,0 \mathrm{Vdc}$ & 30 \\
\cline { 2 - 5 } & $\begin{array}{c}16.00- \\
16.30\end{array}$ & 31 & $3,0 \mathrm{Vdc}$ & 30 \\
\hline \multirow{2}{*}{$17-06-$} & $\begin{array}{c}08.30- \\
09.00\end{array}$ & 29 & $2,9 \mathrm{Vdc}$ & 29 \\
\cline { 2 - 5 } 2015 & $\begin{array}{c}16.00- \\
16.30\end{array}$ & 30 & $3,0 \mathrm{Vdc}$ & 30 \\
\hline
\end{tabular}

Table 2. Measurement of the 808H5V5 analog output

\begin{tabular}{|c|c|c|c|}
\hline \multirow{2}{*}{ Date } & Time & $\begin{array}{c}\text { Analog } \\
\text { output }\end{array}$ & $\begin{array}{c}\text { Display } \\
\text { Zelio } \\
(\%)\end{array}$ \\
\hline \multirow{2}{*}{$\begin{array}{c}14-06- \\
2015\end{array}$} & $08.30-09.00$ & $3,1 \mathrm{Vdc}$ & 69 \\
\cline { 2 - 4 } & $16.00-16.30$ & $2,9 \mathrm{Vdc}$ & 66 \\
\hline $15-06-$ & $08.30-09.00$ & $3,3 \mathrm{Vdc}$ & 71 \\
\cline { 2 - 4 } 2015 & $16.00-16.30$ & $3,0 \mathrm{Vdc}$ & 67 \\
\hline \multirow{2}{*}{$\begin{array}{c}16-06- \\
2015\end{array}$} & $08.30-09.00$ & $3,0 \mathrm{Vdc}$ & 67 \\
\cline { 2 - 4 } & $16.00-16.30$ & $3,2 \mathrm{Vdc}$ & 70 \\
\hline $17-06-$ & $08.30-09.00$ & $3,1 \mathrm{Vdc}$ & 69 \\
\cline { 2 - 4 } 2015 & $16.00-16.30$ & $3,1 \mathrm{Vdc}$ & 69 \\
\hline
\end{tabular}

From the table above it can be seen the results obtained in the analog voltage testing and digital conversion displayed on zelio. The LM35 temperature sensor can work well, namely at the measurement of $30 \mathrm{oC}$ the results are read on a $3.0 \mathrm{Vdc}$ multimeter and the display on the LCD 
is worth $30 \mathrm{oC}$ while the humidity sensor works well at a measurement of $70 \%$. worth $70 \%$ according to the calibration carried out on analog voltages and FBD programs.

Testing is done to find out whether the system can work properly testing is done in eight conditions. The data recorded is the active data of the water pump.

From the test results, it can be concluded that the system works where the output of all conditions can work in accordance with the desired conditions.

Table 3. Test results for the whole system

\begin{tabular}{|c|c|c|c|c|}
\hline \multirow[b]{2}{*}{ Date } & \multirow[b]{2}{*}{ Time } & \multicolumn{2}{|c|}{ Conditions } & \multirow[b]{2}{*}{ Pump } \\
\hline & & $\begin{array}{c}\text { Temperature } \\
\left({ }^{\circ} \mathrm{C}\right)\end{array}$ & $\begin{array}{c}\text { Humidity } \\
\%\end{array}$ & \\
\hline \multirow{2}{*}{$\begin{array}{l}14-06- \\
2015\end{array}$} & $\begin{array}{c}08.30- \\
09.00 \\
\end{array}$ & 31 & 69 & OFF \\
\hline & $\begin{array}{c}16.00- \\
16.30\end{array}$ & 30 & 66 & $\mathrm{ON}$ \\
\hline \multirow{2}{*}{$\begin{array}{c}15-06- \\
2015\end{array}$} & $\begin{array}{c}08.30- \\
09.00\end{array}$ & 30 & 71 & OFF \\
\hline & $\begin{array}{l}16.00- \\
16.30 \\
\end{array}$ & 29 & 67 & OFF \\
\hline \multirow{2}{*}{$\begin{array}{l}16-06- \\
2015\end{array}$} & $\begin{array}{c}08.30- \\
09.00\end{array}$ & 30 & 67 & ON \\
\hline & $\begin{array}{c}16.00- \\
16.30 \\
\end{array}$ & 30 & 70 & ON \\
\hline \multirow{2}{*}{$\begin{array}{l}17-06- \\
2015\end{array}$} & $\begin{array}{l}08.30- \\
09.00\end{array}$ & 29 & 69 & OFF \\
\hline & $\begin{array}{c}16.00- \\
16.30\end{array}$ & 30 & 69 & ON \\
\hline
\end{tabular}

\section{CONCLUSION}

From the results of the trial and analysis conclusions can be obtained, the measurement of the output voltage at the temperature sensor shows that the temperature sensor works as desired, the error obtained is $3.1 \%$ because the comparator used is temperature using mercury (not digital).

The measurement results of the voltage output on the $808 \mathrm{H} 5 \mathrm{~V} 5$ humidity sensor indicate that the sensor works as desired because the error obtained is $5.9 \%$.

The experimental results show that the active water pump is in accordance with the desired setpoint, namely at a temperature of $30 \mathrm{oC}$, humidity $<70 \%$, and active time at 08.30 09.00 and $16.00-16.30$.

\section{ACKNOWLEDGMENT}

The researcher thanked all the Electrical Engineering Study Program lecturers who had provided input, as well as the Dean of the Faculty of Industrial Engineering and the Head of the Electrical Engineering Laboratory of PGRI Adi Buana Surabaya University who had provided facilities in this research process.

\section{REFERENCE}

[1] emir nasrullah, A. Trisanto, and L. Utami, Minasama no kokutetsu desu., vol. 5, no. 3. Nihon Kokuyū Tetsudō, 2012.

[2] T. H. T. M. Herlambang Dwi Utama, "PENGEMBANGAN TRAINER PLC ZELIO SMART RELAY UNTUK MATA PELAJARAN INSTALASI MOTOR LISTRIK," J. Pendidik. Tek. Elektro, vol. 8, no. 3, Oct. 2018.

[3] H. Wicaksono, Programmable Logic Control ( Teori, Pemrograman dan Aplikasinya dalam Otomasi Sistem). Yogyakarta: Graha Ilmu.

[4] M. Diansari, Pengaturan Suhu, Kelembaban, Waktu Pemberian Nutrisi Dan Waktu Pembuangan Air Untuk Pola Cocok Tanam Hidroponik Berbasis Mikrokontroler AVR Atmega 8535. Jakarta: DEPARTEMEN TEKNIK ELEKTRO FAKULTAS TEKNIK UNVERSITAS INDONESIA, 2008.

[5] A. Rahayuningtyas, I. F. Apriyanto, S. I. Kuala, and T. Santoso, "PEMANFAATAN LM35 SEBAGAI SENSOR SUHU OTOMATIS PADA SISEM PENGONTROLAN SUHU RUANGAN PENGERING (STUDI KASUS : PENGERING TIPE RAK)," ETHOS (Jurnal Penelit. dan Pengabdian), vol. 0, no. 0, p. 7, Jan. 2016. 